\title{
EVIDENTIARY MEANS IN FEUDAL TRANSYLVANIA. ORDEAL BY FIRE (HOLDING A RED-HOT IRON)
}

\author{
Dr. MOLDOVAN Iosif Florin \\ Associate Professor \\ UVVG Arad - Faculty of Legal Sciences \\ gerulaflorin@yahoo.com
}

(Received November 2017; Accepted December 2017)

\begin{abstract}
One of the evidentiary means used in medieval legal procedure was the so-called judgment of God, judicium dei, also known as ordeal, from the Latin term ordalium. Ordeals were characteristic of all peoples in their various stages of development. They were based on the belief that divinity could intervene and perform miracles, disregarding the laws of nature, in order to prove one's innocence. In the Middle Ages ordeals were widespread on the territory of Transylvania, too, the ordeal of fire being one of the most commonly used means of proof. In this paper I will try to show the characteristics of this evidence in relation to others that were used at that time, looking at them through the lenses of the documents of the time and of personal research.
\end{abstract}

Keywords: Red-hot iron, trial by ordeal, oath, evidence, trial

Ordeals are juridical institutions that are specific to certain development stages in the evolution of society. They appeared and were used as evidentiary means in the slave society system and in the period of transition to feudalism, the 11th-13th centuries representing their peak age.

They were widespread and were practiced by all the peoples neighbouring Transylvania, being encountered among the Russians, the Poles, the Hungarians, the Czechs, the Serbs and the Bulgarians. In Russia, ordeals were used as evidentiary means along with personal testimony, witness statements and oaths [1]. Russian legislation provided for the use of ordeals, in particular ordeal by fire and ordeal by water. The ordeal of the red-hot iron was imposed upon whose who were accused of homicide or of theft amounting to half a gold hryvnia. If the value of the theft was smaller, of up to two simple hryvnia, the ordeal by water was applied, and if it was even smaller, swearing sufficed [2].

Existing historical records show that trial by fire was called using the Slavic term pravda, in the sense of evidence, trial of justice, truth: "he sent to Oradea ... for testing the truth" (discutiens ad pravdem...misit Waradinum), or simply: "he sent for trial of justice." [3] The name was borrowed from the Slavic population in Hungary and Transylvania, proving the close contact with these peoples.

In Wallachia and Moldova there was an oath with a swath of land on one's head or by carrying a bag filled with earth on one's shoulders. This evidentiary form also 
existed in Transylvania, being used for beating the bounds of various estates and having features in common with ordeals. This custom was based on the belief that the calling the earth as a witness incurred revenge, just like in the case of water, fire and the sun if they were used as evidence ... for the land will not allow the one who has tarnished its purity to live.

Ordeals were of several kinds, most notably: the duel, trial by cross, ordeal by redhot iron, by cold water and hot water, by corpse, the Eucharist, the oath at the tomb of King Ladislaus in Oradea.

Various reminiscences of judiciary duelling were preserved until late in history.

For the trial by cross, the parties stretched their hands to one of the arms of the cross, and the one whose hand got tired and dropped faster was considered guilty.

The ordeal by cold water applied especially to those who were accused of witchcraft. It was carried out at a deep water, running or still. Having had his hands and feet tied, the accused was dropped into the water. If he did not sink, he was considered guilty. Those that sank were considered innocent. Guilty men were burned at the stake.

The ordeal by corpse took into account the reaction of the dead body that was exposed to the accused. If the latter was guilty, the corpse would move or bleed from its wounds.

The ordeal by the Eucharist was based on the belief that God would not allow the guilty to come close to it, but struck them with death or other misfortunes if they dared seek communion.

The ordeal by hot water and red-hot iron was manifested through the effect it was supposed to have it on the one who put his hand into hot water or touched a piece of iron reddened in the fire.

In Transylvania, ordeals were recognized as lawful institutions and were officially regulated. Kings Ladislaus I (1077-1095) and Coloman Cărturau (1095-1116) established myriad rules in this respect [4].

Ladislaus I decided that in the event of joint theft, only one of the accused should be subjected to the ordeal by red-hot iron. He established the proper fee for those who administered the ordeal. King Coloman Cărturaru ordered that the ordeals should be conducted only at the episcopal residences and at the major provostships. In Transylvania, these ordeals were done in Oradea, which was the episcopal residence, and in Arad, where there existed a provostship [5].

The document that shows us cases proven by ordeal, as well as the circumstances in which they were used, is the Chapter of the Diocese of Oradea. In 1208-1235 there were 389 records and minutes. They are known as the Register of Oradea, first printed in Cluj, in 1550, under the title Ritus explorandae veritatis, i.e. The Ceremonial of Learning the Truth. The Register of Oradea was translated only in 1951 , in volume I of DIR, the series $C$. Transilvania, the 11th, 12th, 13th centuries, 
the years 1075-1250.

In what follows, I will present the ordeal by red-hot iron and the oath at the tomb of King Ladislaus I, these ordeals being mentioned in the Register of Oradea.

The Christian Church took ordeals, along with other customs and institutions of pagan origin, and sought to use them to its advantage. Tolerating, at first, and then using and managing these customs, the Church ensured a means of income and influence that priests also made recourse to.

When judges failed to establish the truth in the trials they presided over, they sent the litigants to places where the ordeal by red-hot iron was administered, as the resolution of the conflict was expected from this evidence. The ordeal was conducted on a Sunday or another holiday, in the church or in the courtyard of the church. The ceremonial was performed by priests, in the presence of witnesses, of the representatives or the head of the Chapter of the Church in Oradea and the bellman of the judge who had demanded that the ordeal be administered. Those who were to be subjected to this evidentiary trial prepared thus: it was compulsory to fast on bread and water for three days; their hands were bandaged lest there should be any suspicions with respect to a possible treatment that might prevent the effect of the trial.

The manner in which evidence was collected: while the iron was reddening in the fire, mass was celebrated; during this time, the one subjected to the ordeal was given communion. He was warned not to comply if he felt guilty. After pleading innocent, the defendant took the red-hot iron, which weighed $1-1.5 \mathrm{~kg}$, vowing that he had not resorted to charms or herbs to prevent the effect of the fire, and carried the iron in his hand for 9 or 12 steps. Then his hand was tied with a bandage that was sealed. After 8 days, the seal was checked so as not to be broken and so that the hand could be looked after. If the seal was intact, the wound dressing was unwrapped, and if the wound had healed in this time frame, the innocence of the one subjected to the ordeal was pronounced. Otherwise, the judge passed upon the guilty the due civil or criminal sentence under the law and according to the customs.

All cases sent for trial by ordeal in Oradea were proven through the ordeal by redhot iron, except for nine cases in which an oath was pledged at the tomb of King Ladislaus I [6].

The ordeal by red-hot iron was called iudicium ferri candentis, examen ferri candentis. It was complied with by one of the parties, either the accused or the accuser. The party that did not show up on the set date was considered guilty and lost the lawsuit. About the one who succeeded in passing the ordeal, it was said: justificatus est, mundatus est, i.e. he justified himself, was cleared of accusations and proved his innocence. When the one subjected to the ordeal failed, it was said: combustus est, convictus est, i.e. he got burned, he condemned himself. 
In the feudal society, the rules of law, which were for the most part unwritten, were raised to the rank of law by the will of the feudal class. They entrenched the feudal's full ownership over the means of production and incomplete ownership over the producer, the serf, over whom he had no right to life, but whom he could sell, buy and force to work. Because the ruling class of the great landowners had its own legal institutions, its members were not subjected to ordeal by red-hot iron. This ordeal was used only for the middle and lower walks of life, respectively, serfs of different categories, dependent serfs, bondsman, servants, slaves, freed slaves and craftsmen. The most numerous categories that had to go through this ordeal was that of free peasants, who filed actions amongst themselves or against the members of other, usually lower categories, such as serfs or slaves. These lawsuits were won at random.

The class character of the ordeal by red-hot iron stands out if we analyse the subject of the various litigations for which evidence was sought. Thus of the 389 cases, over two hundred referred to property damage by theft, violence and robbery. Most of the cases related to theft, the allegations being proven by recourse to ordeal by red-hot iron.

Ordeal by red-hot iron was a characteristic means of proof, as an expression of the will of the ruling class in the society of those times, in which it was used and in which it served as an instrument for maintaining the exploitation of and inequality between people. The masters, the great feudal lords, were not subjected to this ordeal, being considered degrading by and for them. Also, the members of the middle class, who could decide the fate of other people, had others carry the redhot iron in their place, a process that makes it clear that the ordeal was but a means of possession and exploitation in the hands of the feudal landowners, based on ignorance and superstitious faith specific to the feudal era.

\section{Notes}

1. Florin I. Moldovan, Originea și evoluția instituției jurătorilor la români (Dej: Ed. Texte, 2007), 30.

2. Moldovan, Originea și evoluția, 31.

3. DIR-C.Transilvania, vol.I, Registrul de la Oradea, PV no. 9,10,11,14,18,31.

4. St. Endliecher, Rerum Hungaricarum monumenta arpadiana, Sankt Galen, 1849, reprinted in Lepipzig, 1931, 335-336, 341, 346, 365, 369, 370, apud Ion Sabău, Studii privind Istoria României (Bucuresti: Ed. Academiei Române, 1953), 625 and passim.

5. DIR.C.Transilvania, Vol. I, Registrul de la Oradea, no. 358.

6. DIR.C.Transilvania, Vol. I, no. 161,166, 229, 230, 315, 340, 356, 362, 387 